\title{
Pemanfaatan E-Learning Untuk Inovasi Pembelajaran Aksara Jawa Bagi Siswa Sekolah Menengah Atas
}

\author{
Aditya W. Mahastama ${ }^{\# 1}$, Lucia D. Krisnawati ${ }^{\# 2}$, Laurentius Kuncoro Probo Saputra ${ }^{\# 3}$

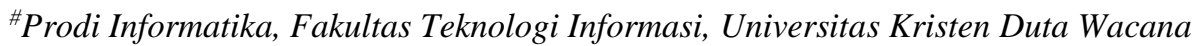 \\ Jl. Dr. Wahidin Sudirohusodo 5-25, Yogyakarta \\ 1 mahasestaff.ukdw.ac.id \\ 2krisnaestaff.ukdw.ac.id \\ ${ }^{3 k u n c o r o d s t a f f . u k d w . a c \cdot i d}$
}

\begin{abstract}
Abstrak - Indonesia adalah bangsa yang terdiri dari berbagai suku dengan tradisi, bahasa dan kearifan lokal yang kaya. Namun, minat generasi masa kini untuk mempelajari dan menerapkan budaya daerahnya semakin menipis, terutama dalam mempelajari bahasa dan aksara daerahnya. Hal ini menjadi tantangan bagi para pengajar dalam menyampaikan materi pelajaran budaya daerah sebagai muatan lokal kepada para siswa di sekolah, termasuk di sekolah-sekolah menengah atas di Daerah Istimewa Yogyakarta. Dengan kondisi lingkungan yang semakin longgar dalam menerapkan aspekaspek budaya dan heterogennya daerah asal siswa, pengajaran bahasa dan aksara Jawa membutuhkan inovasi untuk meningkatkan minat belajar siswa, sekaligus memudahkan siswa dengan berbagai latar belakang budaya untuk menerima pelajaran. Pengembangan aplikasi belajar aksara Jawa berbasis web menjadi bagian solusi bagi permasalahan tersebut. Aplikasi ini dirancang dengan aspekaspek yang disesuaikan dengan kebiasaan siswa saat ini yang terbiasa menggunakan gawai, serta menerapkan prinsipprinsip pembelajaran yang lebih menekankan pada aspek perulangan dari pada hafalan untuk memberikan pengalaman belajar yang baru dan menarik. Tim pengabdian kepada masyarakat melakukan kegiatan pendampingan penggunaan Aplikasi Belajar Aksara Jawa secara luring dan daring pada sekolah-sekolah mitra, yaitu SMA Immanuel Kalasan dan SMA Budya Wacana Yogyakarta untuk meningkatkan daya serap pembelajaran aksara Jawa pada mata pelajaran Bahasa Jawa. Pengembangan aplikasi berbasis web ini juga bertepatan dengan dilaksanakannya pembelajaran daring mengikuti penerapan protokol kesehatan selama wabah COVID-19, sehingga sekaligus menjadi solusi yang tepat guna bagi siswa yang saat ini belajar secara daring dari rumah.
\end{abstract}

Kata Kunci-e-learning, aksara jawa, sekolah menengah atas

Abstract-Indonesia is widely known for having a vastly diverse and rich cultures. Albeit attempts to preserve those local cultures, namely including it as a subject in the local formal education, the interest of younger generations to keep these cultures alive are declining over the years, due to the cultures getting loosely practiced in their home environments and the effects of globalization. This poses a challenge for the teachers to innovate to keep up with the condition, including in the region of Daerah Istimewa Yogyakarta, which is regarded as one of the centers for Javanese culture. As a center of education as well, schools in Yogyakarta are having students from all corners of Indonesia, which added the challenge of educating Javanese culture to non-Javanese. A web-based elearning tool might be a solution: we developed an application for learning Javanese Scripts with aspects suited to the current habits of today's students, and considering as well the aspect of learning by repetition rather than memorizing, to help the students coming from outside of the Javanese cultural area. The application is currently used by Budya Wacana and Immanuel High Schools to help improving the learning quality of Bahasa Jawa (Javanese Languange) subject, especially in understanding Javanese scripts. The usage of the application is also happened to be in time with the distant learning notice issued by the government of Indonesia due to the pandemic health protocol, thus providing an alternative way to complement online learning for high school students.

Keywords-e-learning, Javanese script, high school education.

\section{Pendahuluan}

\section{A. Latar Belakang}

Indonesia adalah bangsa yang dikenal memiliki budaya yang kaya, di mana setiap suku bangsa memiliki budayanya masing-masing beserta kearifan lokal yang terkandung di dalamnya [1]. Tidak terkecuali budaya Jawa yang ngrembaka di daerah Jawa Tengah, Jawa Timur dan Daerah Istimewa Yogyakarta.

Patut disayangkan, generasi muda masa kini semakin hari semakin tidak menerapkan unsur-unsur budaya tersebut dalam kehidupannya sehari-hari secara utuh, baik itu adat istiadat, kebiasaan, maupun bahasa dengan baik dan benar sesuai tatanan budaya setempat. Hal ini dikarenakan orang tua dan masyarakat semakin terkena dampak globalisasi [2] di mana relasi dan komunikasi antar manusia lebih pada 
sesuai kebutuhan saja, sehingga aspek-aspek budaya pada akhirnya direduksi menjadi apa yang perlu saja dalam kehidupannya, misalnya etika yang menjadi seragam di manapun kita berada dan bahasa yang sekarang lebih mengarah pada lingua franca dari pada usaha untuk melestarikan bentuk baku bahasa setempat. Sekalipun jumlah penutur bahasa Jawa mencapai lebih dari 60 juta [3], tetapi tidak banyak orang bisa membaca dan menulis aksara Jawa dengan lancar, sedangkan budaya lokal termasuk bahasa, memuat local wisdom yang memiliki peran penting sebagai penyusun kebudayaan bangsa [4].

Pemerintah, dalam hal ini melalui Dinas Pendidikan, sebenarnya telah berusaha agar budaya lokal tetap diperkenalkan dalam tataran pendidikan awal (pendidikan dasar dan menengah). Penyelenggaraan mata pelajaran Bahasa Jawa ini diwajibkan secara legal dengan adanya Peraturan Gubernur (PerGub) Provinsi Daereah Istimewa Yogyakarta no 64 tahun 2013. Pergub ini menyatakan bahwa mata pelajaran bahasa Jawa menjadi mata pelajaran muatan lokal yang wajib diajarkan di sekolah-sekolah atau Madrasah baik di tingkat dasar, menengah maupun atas di wilayah Daerah Istimewa Yogyakarta. Namun mengingat kondisi penerapan budaya yang bertolak belakang di masyarakat, maka tantangan yang dihadapi para pendidik untuk menularkan budaya lokal menjadi lebih berat dari pada dekade-dekade sebelumnya, di mana penerapan budaya di masyarakat masih kuat.

\section{B. Rumusan Masalah}

Bagi sekolah-sekolah menengah di wilayah Daerah Istimewa Yogyakarta, tantangan serupa dihadapi tidak hanya dari kondisi siswa yang terdiri dari siswa lokal yang sudah terkikis penerapan budayanya dan banyaknya siswa dari luar daerah yang bukan berlatar budaya Jawa, tetapi dari sisi pendidik dan kebijakan sekolah. Beberapa sekolah, meskipun telah diimbau untuk menyelenggarakan mata pelajaran Bahasa Jawa yang menjadi muatan lokal dan diharapkan juga berisi aspek budaya dan unggah-ungguh, justru memilih tidak menyelenggarakan mata pelajaran Bahasa Jawa, karena tidak ada teguran berarti. Hal ini juga ditambah dengan kurangnya jumlah pendidik (guru) yang mampu untuk mengampu mata pelajaran tersebut.

Kondisi serupa dihadapi oleh Sekolah Menengah Atas Immanuel, Kalasan dan Sekolah Menengah Atas Budya Wacana, Yogyakarta. Kepala sekolah beserta para guru sebenarnya mendukung semangat Dinas Pendidikan untuk tetap menjadi "penular" budaya Jawa bagi siswa-siswinya, tetapi kondisi lingkungan siswa, kebiasaan anak-anak generasi Z (kelahiran 1995-2010) dan generasi Alpha (lahir sesudah 2010) yang sedang menjadi siswa-siswi mereka [5] serta komposisi asal siswa yang heterogen membuat para pendidik senantiasa mencari metode baru yang tepat untuk menyampaikan mata pelajaran tersebut.

Menilik kondisi tersebut, kehadiran teknologi masa kini semestinya dapat dimanfaatkan untuk membantu pembelajaran budaya dan bahasa Jawa. Teknologi tersebut hendaknya juga selaras dengan kebiasaan generasi $\mathrm{Z}$ dan Alpha yang piawai menggunakan komputer serta gawai sebagai sumber informasi utama [6]. Fakultas Teknologi Informasi Universitas Kristen Duta Wacana Yogyakarta, melalui tim penelitian TRAWACA telah memulai penelitian di bidang pemanfaatan teknologi informasi untuk digital humanities, terutama pelestarian manuskrip Jawa dalam bentuk digitalisasi melalui optical character recognition (OCR) yang mengarah pada transliterasi, serta menghasilkan produk aplikasi yang dapat membantu kegiatan belajar aksara Jawa. Tim Pengabdian kepada Masyarakat Universitas Kristen Duta Wacana (PkM UKDW) bermaksud menerapkan produk penelitian ini, berkoordinasi dengan SMA Immanuel Kalasan dan SMA Budya Wacana selaku sekolah mitra dalam bentuk pendampingan penggunaan teknologi tepat guna berupa aplikasi web untuk pembelajaran aksara Jawa. Aplikasi ini akan disesuaikan agar memiliki aspek-aspek visual yang familiar untuk digunakan oleh generasi Z dan Alpha [7], serta kebiasaan belajar mereka sehingga dapat membantu belajar aksara Jawa dengan cara asimilasi ilmu melalui pembiasaan, bukan hafalan. Diharapkan siswa-siswi SMA Immanuel Kalasan dan SMA Budya Wacana dapat lebih nyaman dan lebih mengerti dalam belajar aksara Jawa, yang merupakan bagian dari mata pelajaran Bahasa Jawa.

\section{Tinjauan Pustaka}

Dengan tujuan memperkenalkan cara dekomposisi serta urutan penulisan aksara Jawa kompleks kepada masyarakat umum, khususnya kepada generasi muda, Krisnawati dan Mahastama [8] melakukan pelatihan anotasi atau pelabelan aksara Jawa. Pelatihan Anotasi ini dilakukan dengan menggunakan aplikasi yang dinamai Cakra dan yang dilakukan dengan beberapa metode yakni, tatap muka, lokakarya, dan urun daya (crowdsourcing) [8].

Dilakukan sebelum masa pandemi, Suharyanto dan Mailangkay [9] melakukan studi pustaka tentang penerapan E-Learning sebagai alat bantu pengajaran di beberapa lembaga pendidikan. Hasil penelitian tersebut menunjukkan bahwa E-learning berpengaruh positif dan signifikan terhadap mutu belajar siswa. Menurutnya, intensitas belajar siswa lewat e-learning meningkatkan juga mutu kualitas belajar siswa [9], hanya, seberapa persen peningkatannya tidak diukur secara kualitatif. Selain itu, di masa pandemi, siswa dipaksa untuk belajar secara daring.

Pemilihan peserta pendampingan perlu dilakukan secara baik sehingga dapat mencapai target bahwa pembelajaran aksara jawa berbasis e-laerning ini bisa menjadi solusi 
inovatif bagi penggunanya. Peserta pendampingan harus memiliki kompetensi yang baik terkait Bahasa Jawa dan pengetahuan teknis terkait e-learning. Hal tersebut akan sangat mendukung keefektifan sebuah proses pendampingan dan penerapan e-learning [10]. Oleh karena itu, untuk proses pendampingan ini peserta pendampingan dipilih yang memiliki kompentensi di bidang Bahasa Jawa dan Teknologi Informasi (IT).

\section{Persiapan Kegiatan}

\section{A. Identifikasi Kebutuhan Mitra}

Sesuai dengan permasalahan pembelajaran aksara Jawa yang dihadapi oleh SMA Immanuel Kalasan dan SMA Budya Wacana, disepakati bersama kedua mitra bahwa penerapan teknologi tepat guna tersebut berupa penyediaan layanan aplikasi belajar aksara Jawa bagi siswa-siswi dan guru SMA Immanuel Kalasan dan SMA Budya Wacana disertai pendampingan penggunaannya. Menyesuaikan dengan kondisi infrastruktur teknologi informasi kedua mitra sekolah yakni adanya jaringan Internet dan laboratorium komputer yang dilengkapi peramban, maka aplikasi memungkinkan untuk dibuat berbasis web.

Aplikasi ini dirancang untuk dapat menampilkan soal berupa aksara Jawa dalam bentuk citra soal dan jawaban dalam bentuk aksara Jawa Unicode. Aplikasi dibuat berbasis web agar dapat diakses oleh siswa dan guru menggunakan gawai apa saja dan dengan waktu yang fleksibel. Pengguna aplikasi ini dibagi menjadi dua:

1) Siswa

Aplikasi digunakan oleh siswa untuk belajar aksara Jawa dengan cara mengerjakan soal dan mengumpulkan. Soal berupa baris-baris tulisan beraksara Jawa yang harus diidentifikasi penyusunnya dalam satuan suku kata aksara Jawa yang terdiri dari satu buah aksara nglegena beserta semua sandhangan dan pasangan-nya. Selain aksara ngelegena, terdapat pula pratandha (tanda baca) dan angka Jawa. Siswa akan memilih dan menata susunan aksara Jawa yang sesuai dengan soalnya, kemudian mengumpulkan pekerjaannya secara daring.

2) Guru

Guru dapat memberikan tugas untuk mengerjakan soal dari aplikasi, menerima pekerjaan siswa dan mengevaluasinya. Dalam proses evaluasi, guru dapat memberi tanda satuan aksara mana saja yang tidak tepat, memberikan koreksi, memberikan komentar dan memberi nilai.

Dengan demikian penggunaan aplikasi ini diharapkan tepat sasaran dan memberikan manfaat tidak hanya untuk siswa, guru, tetapi sivitas akademika sekolah secara umum. Siswa tidak hanya mengerjakan soal dan melihat nilai akhir, tetapi melalui proses pendidikan juga dengan mengetahui aksara mana yang salah. Demikian juga guru dengan melakukan evaluasi akan terus mengasah kemampuan dan ilmunya di bidang bahasa Jawa.

Persiapan aplikasi dan pelaksanaan pendampingan penggunaan aplikasi dilakukan oleh Tim Pengabdian Kepada Masyarakat (PKM) UKDW. Mitra sekolah berpartisipasi dengan menyediakan infrastruktur teknologi informasi bagi sivitasnya masing-masing untuk mengakses aplikasi, serta menyediakan tempat bagi pelaksanaan pendampingan penggunaan aplikasi berupa laboratorium komputer. Tim PKM UKDW juga menyediakan dukungan teknis bagi siswa dan guru SMA Immanuel Kalasan dan SMA Budya Wacana dalam menggunakan aplikasi. Aplikasi diinangkan di penginangan umum agar aksesnya dapat berlanjut untuk dimanfaatkan oleh sekolah mitra maupun pihak-pihak yang membutuhkan di kemudian hari.

\section{B. Rencana Pelaksanaan Kegiatan}

Menilik kebutuhan yang diperlukan oleh sekolah mitra, Tim PkM melakukan profile matching dengan aplikasi yang sudah dimiliki oleh Tim Penelitian TRAWACA di Fakultas Teknologi Informasi UKDW. Tim TRAWACA memiliki aplikasi dasar mengenai olah aksara Jawa yang dapat dikembangkan menjadi tepat guna bagi pembelajaran aksara Jawa bagi siswa sekolah menengah atas. Untuk itu Tim PkM melakukan penyesuaian terhadap aplikasi tersebut hingga akhir bulan Maret 2020. Jadwal ini menyesuaikan jadwal pelaksanaan Ujian Nasional (UN), di mana target siswa mitra yaitu siswa kelas X dan XI sudah kembali rutin masuk sekolah setelah kelas XII melaksanakan UN.

Direncanakan pada akhir bulan Maret 2020 atau awal April 2020 (mengikuti jadwal sekolah mitra), pendampingan penerapan teknologi tepat guna dimulai dengan mengadakan pelatihan penggunaan aplikasi bagi siswa dan guru sekolah mitra. Setelah itu, selama masa pelaksanaan PkM, Tim PkM UKDW memberikan pendampingan teknis dalam pemanfaatan dan penerapan aplikasi belajar aksara Jawa. Pada akhir masa PkM juga akan diadakan evaluasi bersama antara Tim PkM UKDW dan sekolah mitra terhadap ketepatgunaan aplikasi terhadap pembelajaran Bahasa Jawa di sekolah mitra.

\section{Metode Pelaksanaan}

Kegiatan PkM ini menerapakan beberapa metode yang menyesuaikan kondisi dan kebutuhan pelaksanaan kegiatan dan mitra sekolah:

1) Tatap muka langsung. Rencana pelaksanaan adalah dengan melakukan pendampingan penggunaan Aplikasi Belajar Aksara Jawa di lokasi sekolah-sekolah mitra pada jam pelajaran Bahasa Jawa, bersama dengan guru mata pelajaran dan siswa-siswa sekolah mitra. Metode ini mengalami perubahan implementasi oleh karena pandemi dan aturan PSBB yang diterapkan. 
2) Lokakarya. Pelatihan dan pendampingan bagi para guru yang akan menggunakan Aplikasi Belajar Aksara Jawa, dikemas dalam bentuk lokakarya, dengan tujuan selain melatih para guru juga mengumpulkan masukan untuk perbaikan aplikasi.

\section{PELAKSANAAN KEgIATAN}

\section{A. Persiapan Aplikasi Belajar Aksara Jawa}

Kegiatan Pengabdian kepada Masyarakat yang bermitra dengan SMA Immanuel Kalasan dan SMA Budya Wacana Yogyakarta ini menggunakan program bantu Aplikasi Belajar Aksara Jawa. Aplikasi ini merupakan penyesuaian dari produk penelitian Tim TRAWACA Fakultas Teknologi Informasi Universitas Kristen Duta Wacana yang memiliki bidang minat digitalisasi aksara Jawa. Aplikasi tersebut berjalan di server penelitian TRAWACA dan dapat diakses melalui menu Aplikasi / Belajar Aksara Jawa pada https://trawaca.id, atau melalui https://trawaca.id/sinau. Tampilan halaman depan aplikasi ini ditunjukkan oleh Gambar 1 berikut.

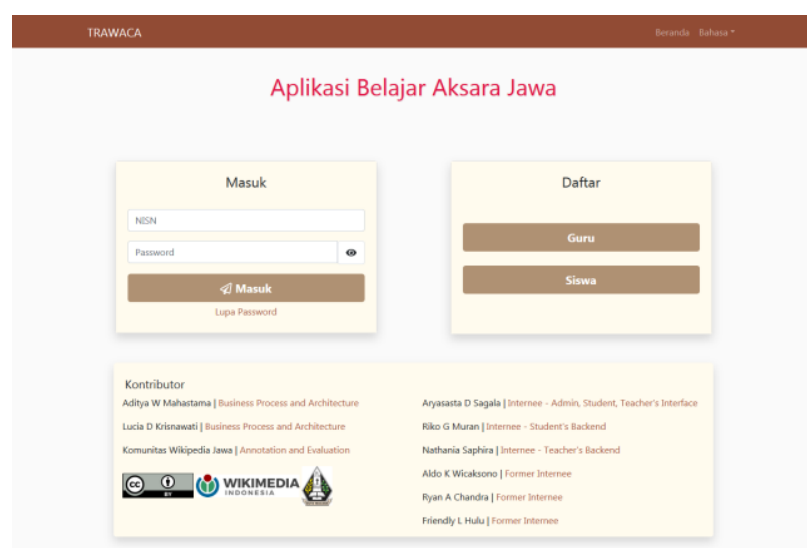

Gambar 1. Tampilan Halaman Depan Aplikasi Belajar Aksara Jawa

Aplikasi ini memiliki fungsi sebagai sarana belajar dan mengajar aksara Jawa. Bagi siswa, aplikasi ini menyajikan soal-soal latihan berupa baris-baris aksara Jawa yang dapat dipilih dari lembar-lembar buku beraksara Jawa. Baris-baris tersebut kemudian dikerjakan oleh siswa dengan cara mengidentifikasi elemen-elemen aksara satu per satu. Kekhasan dari aplikasi ini adalah saat siswa harus mengidentifikasi sebuah aksara atau elemen aksara, maka ia dapat memilih jenis elemen aksara sesuai penggolongannya (Carakan, Pasangan, Sandhangan, Angka, Aksara Murda, dsb.), kemudian muncul daftar aksara yang termasuk dalam golongan tersebut disertai dengan wujud aksaranya dalam font UNICODE. Hal ini akan membantu siswa, terutama yang berasal dari luar daerah berbahasa Jawa, untuk mengingat dengan cara terbiasa, yang merupakan aspek kognitif dari pembelajaran. Tampilan tersebut ditunjukkan oleh Gambar 2 dan 3. Setelah selesai mengerjakan, siswa akan mengumpulkan pekerjaan tersebut untuk dapat dievaluasi oleh guru mata pelajaran Bahasa Jawa.

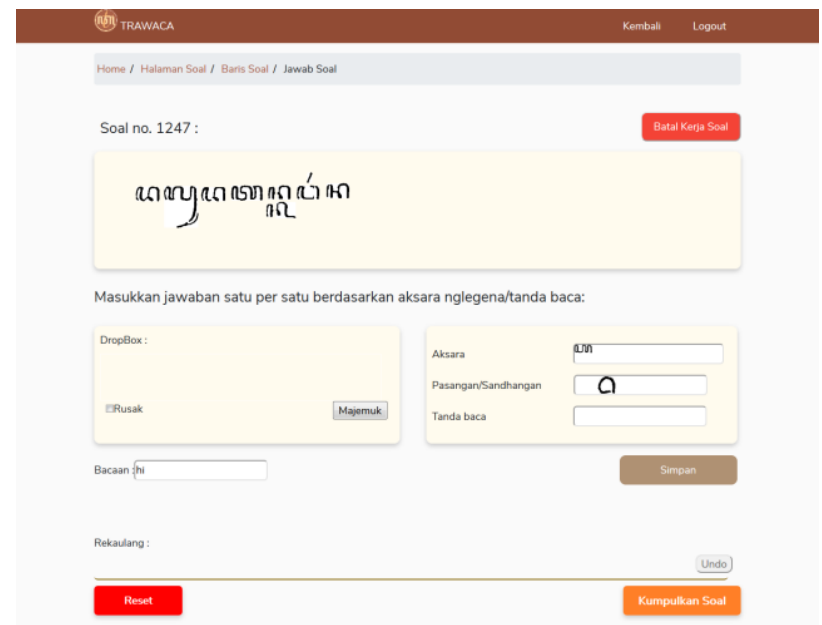

Gambar 2. Tampilan Antar Muka Mengerjakan Soal Kalimat Aksara Jawa

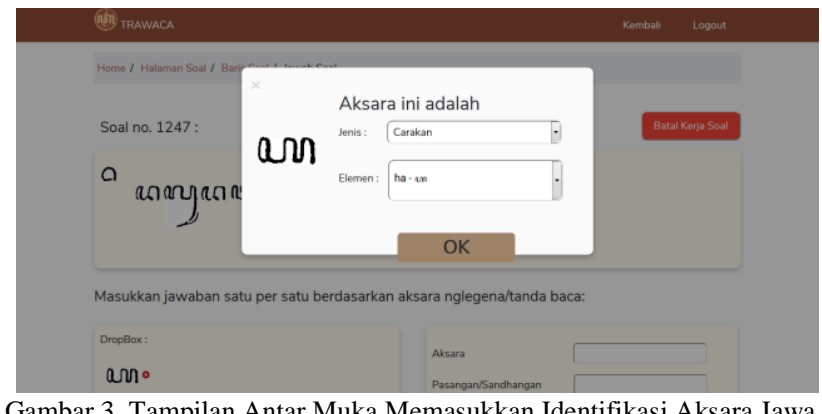

Selain itu, siswa dapat juga melihat hasil evaluasi dan penilaian yang diberikan oleh gurunya melalui antar muka 'Lihat Nilai'. Kekhasan yang ada di sini adalah bahwa koreksi atau pembetulan dapat dilihat oleh siswa per elemen aksara yang dikerjakan, sehingga dapat membantunya memperbaiki kesalahan, tidak hanya melihat nilai akhir saja.

Bagi guru mata pelajaran Bahasa Jawa, disediakan antar muka untuk melihat hasil pekerjaan siswa dan mengevaluasinya, seperti ditunjukkan pada Gambar 4. Selain melakukan evaluasi, guru juga dapat memberikan penilaian bagi pekerjaan siswa dengan angka seperti pada Gambar 5. Penilaian tidak diberikan secara otomatis oleh sistem karena itu merupakan kebijakan guru, dan juga siswa mungkin ada yang tidak mengerjakan seluruh aksara pada sebuah kalimat soal, sehingga penilaian otomatis tidak sesuai untuk diterapkan. 


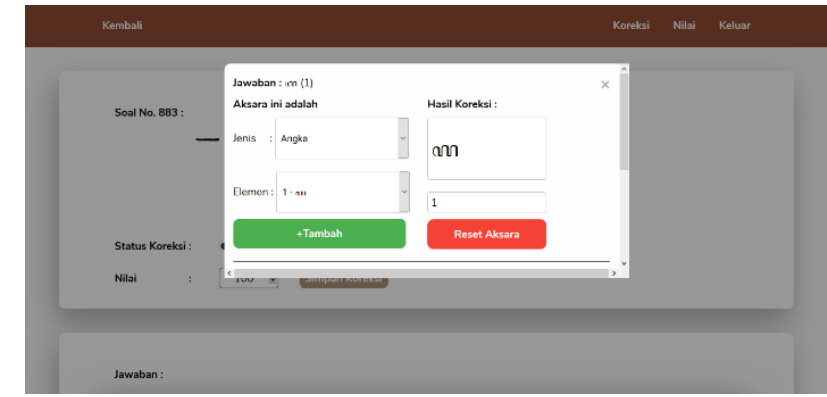

Gambar 4. Tampilan Antar Muka Evaluasi dan Koreksi untuk Guru

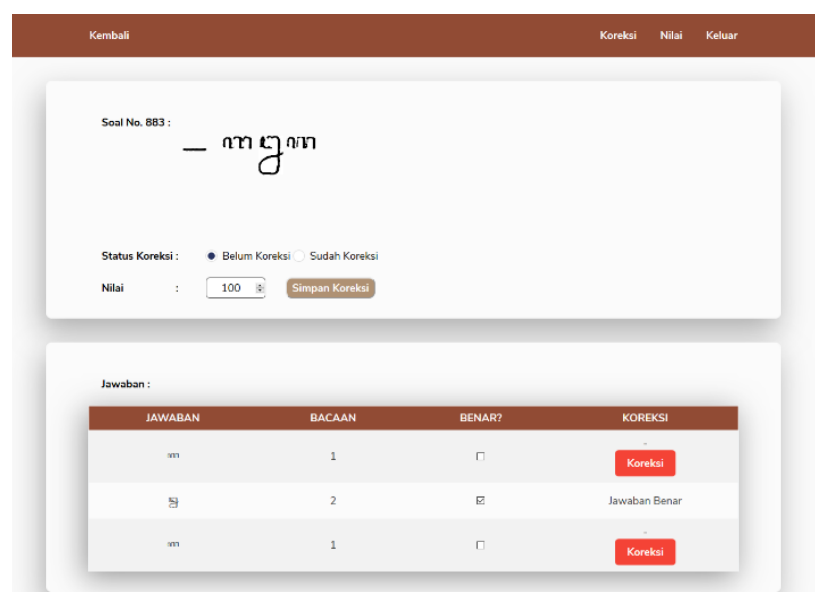

Gambar 5. Tampilan Antar Muka Evaluasi dan Pemberian Nilai oleh Guru

Aplikasi ini telah mengalami penyempurnaan dari versi tahun sebelumnya berdasarkan masukan dari mitra pengabdian pada periode sebelumnya. Penyempurnaan ini dilakukan pada periode PkM ini dan melibatkan satu (1) orang mahasiswa yang membantu dalam pelaksanaan kegiatan PkM ini.

\section{B. Penyusunan Panduan Penggunaan Aplikasi Belajar} Aksara Jawa

Tim telah melakukan penyusunan Panduan Penggunaan Aplikasi Belajar Aksara Jawa sebagai pedoman pendamping bagi guru dan siswa pada sekolah mitra. Panduan ini tersedia dalam tautan pada menu awal untuk guru dan siswa. Keberadaan panduan ini diharapkan dapat membantu guru dan siswa untuk menggunakan aplikasi ini secara mandiri. Panduan ini tersedia dalam format PDF sehingga dapat diunduh dan dibaca secara luring.

\section{Kegiatan Koordinasi dengan Mitra}

Tim PkM telah mengadakan kunjungan dan pembicaraan awal dengan sekolah-sekolah mitra, yaitu dengan SMA Immanuel Kalasan yang diterima oleh Kepala SMA Immanuel Kalasan. Pertemuan ini kemudian ditindak lanjuti dengan pembuatan Surat Pernyataan Kesediaan Bekerja Sama tertanggal 4 Februari 2020, dengan rencana semula pelaksanaan program setelah ujian kelas XII (sekitar bulan Mei-Juni 2020). Pada saat kunjungan ini dibahas kesiapan mitra dan kesediaan guru-guru mata pelajaran Bahasa Jawa untuk mendukung pelaksanaan kegiatan PkM, dan mendapatkan tanggapan yang antusias oleh kepala sekolah maupun para guru dan penanggungjawab teknologi informasi sekolah. Pada kesempatan ini didemonstrasikan penggunaan antar muka program aplikasi untuk memberikan gambaran pada mitra. Koordinasi selanjutnya dilakukan secara daring melalui WhatsApp. Namun seiring diterapkannya PSBB dan perubahan pelaksanaan kegiatan belajar-mengajar (KBM) di SMA tersebut, rencana pelaksanaan ditunda dengan waktu yang belum ditentukan. Hingga akhir masa pelaksanaan PkM, Tim belum berkesempatan kembali untuk melanjutkan kunjungan sesuai dengan rencana pelaksanaan.

Sementara itu, korespondensi dengan mitra SMA Budya Wacana Yogyakarta dibuka melalui pembicaraan informal mengenai kemungkinan-kemungkinan pelaksanaan PkM dengan Kepala Sekolah SMA Budya Wacana Yogyakarta, dan ditindak lanjuti dengan pembuatan Surat Pernyataan Kesediaan Bekerja Sama tertanggal 4 Februari 2020. Kunjungan formal baru dilaksanakan kemudian, dengan pertemuan yang dihadiri Tim PkM, Kepala SMA Budya Wacana Yogyakarta, perwakilan guru Teknologi Informasi dan Komputer (TIK), serta guru mata pelajaran Bahasa Jawa. Pada awal pertemuan didemonstrasikan juga aplikasi dasar yang akan digunakan dalam kegiatan PkM.

Pada tanggal 9 September 2020 Tim PkM mendapatkan kesempatan untuk memperkenalkan aplikasi tersebut melalui pelatihan singkat kepada guru Bahasa Jawa mengenai penggunaan antar muka guru dan siswa untuk mengenal lebih dalam program aplikasi belajar aksara Jawa, seperti ditunjukkan oleh Gambar 7. Pada kesempatan ini guru mata pelajaran Bahasa Jawa mencoba fungsi untuk melakukan registrasi, menambah kelas diampu, melakukan koreksi dan memberi nilai pekerjaan siswa.

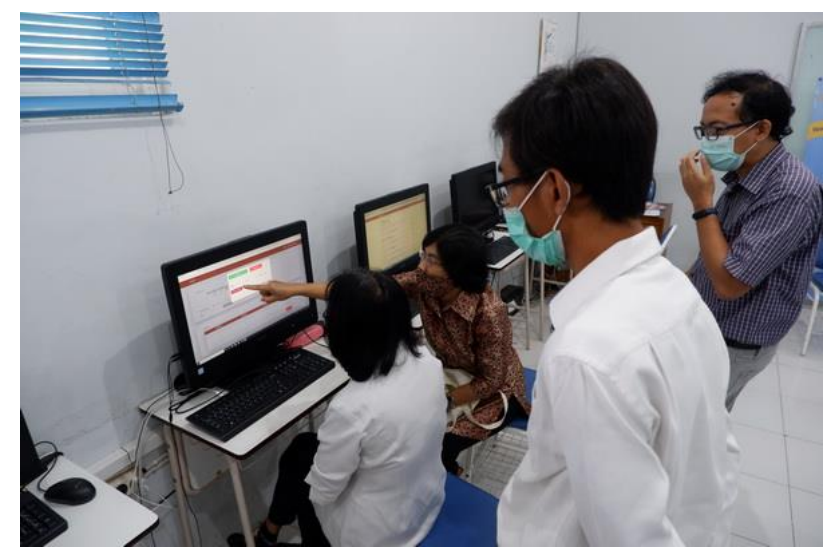

Gambar 7. Pelatihan Singkat Penggunaan Aplikasi di SMA Budya Wacana

D. Adaptasi Kegiatan Berkenaan Pandemi COVID-19 
Adanya pandemi COVID-19 yang menimpa Indonesia sejak awal tahun 2020 menyebabkan dikeluarkannya instruksi untuk Pembatasan Sosial Berskala Besar (PSBB) dan ditetapkannya protokol kesehatan khusus untuk pandemi tersebut. Hal ini berdampak pada dihentikannya tatap muka luring untuk kegiatan belajar mengajar, termasuk pada kedua sekolah mitra yaitu SMA Immanuel Kalasan dan SMA Budya Wacana. Dampak lain adalah sekolah mitra lebih mengutamakan penyesuaian terhadap kelangsungan kegiatan internal dalam sekolahnya dengan PSBB dan protokol baru tersebut.

Bagi tim Pengabdian kepada Masyarakat, hal ini berarti penundaan pelaksanaan rencana kegiatan PkM di sekolah mitra, dan menunggu keputusan dari sekolah-sekolah mitra mengenai bagaimana Kegiatan Belajar Mengajar (KBM) pada sekolah mitra akan dilaksanakan, karena rencana PkM semula akan diimplementasikan sebagai bagian mata pelajaran Bahasa Jawa, dan diberikan pada jam pelajaran reguler. Setelah penetapan keputusan bahwa KBM dilaksanakan secara daring dan Tim PkM melakukan koordinasi dengan pihak sekolah mitra, ditemukan bahwa beberapa hal harus disesuaikan oleh Tim PkM untuk dapat tetap melaksanakan rencana kegiatan semula. Demikian pula dengan target luaran, mengalami penyesuaian dengan kondisi lapangan. Adapun adaptasi dan transformasi pelaksanaan PkM ini adalah penyesuaian metode pelaksanaan PkM.

Semula, seluruh kegiatan PkM dirancang untuk dilaksanakan secara tatap muka dengan cara Tim PkM memberikan instruksi selama kegiatan sosialisasi, pelatihan dan pendampingan penggunaan aplikasi baik untuk guru maupun siswa dan dilaksanakan di sekolah mitra. Dengan adanya keputusan penyelenggaraan KBM secara daring, maka Tim PkM melakukan adaptasi bahwa pelatihan langsung hanya akan diberikan kepada guru-guru mata pelajaran dan dengan pertimbangan protokol kesehatan, dilaksanakan dengan mengundang para guru ke Laboratorium Komputer UKDW pada bulan Oktober 2020.

Selanjutnya para guru mendiseminasikan hasil pelatihan pada siswa-siswinya secara daring dalam lingkup pelaksanaan KBM mata pelajaran Bahasa Jawa dengan jumlah pertemuan yang dirasa cukup oleh para guru, disertai sesi pendampingan dan tutorial oleh Tim PkM secara daring sampai dengan berakhirnya periode PkM pada 31 Oktober 2020. Setelahnya periode tersebut, para guru dan siswa tetap dapat mempergunakan aplikasi tersebut dengan dukungan teknis dari anggota Tim PkM.

Selain itu, untuk mengakomodasi adaptasi pelaksanaan kegiatan PkM yang diperlukan dan penyesuaian terhadap protokol dan aturan kondisi pandemi yang telah didiskusikan dengan mitra $\mathrm{PkM}$, maka sebagian dari anggaran disesuaikan peruntukannya untuk mendukung adaptasi kegiatan daring dan memenuhi protokol kesehatan yang berlaku. Salah satu contohnya adalah pembelian webcam untuk menunjang pendampingan daring secara live, kemudian alokasi dana untuk pembelian alat-alat penunjang protokol kesehatan seperti masker, hand sanitizer dan face shield bagi Tim PkM dan personel sekolah mitra. Realokasi anggaran ini menyesuaikan dengan penyesuaian kebutuhan saat pelaksanaan di lapangan.

Hal yang belum dapat terlaksana dari rangkaian kegiatan PkM ini adalah evaluasi penggunaan Aplikasi Belajar Aksara Jawa oleh siswa, karena hingga masa pelaksanaan PkM berakhir, kesempatan untuk mengujicobakan secara penuh dan melakukan evaluasi belum dapat terlaksana Diharapkan pada kegiatan PkM selanjutnya, kerja sama dengan sekolah mitra dapat dilanjutkan agar seluruh kegiatan PkM dapat dituntaskan sesuai rencana pada periode lain.

\section{E. Pelaksanaan Pelatihan untuk Guru-Guru Sekolah Mitra}

Merujuk pada adaptasi kegiatan yang disebutkan pada subbab D, maka Tim PkM setelah melakukan dengar pendapat dengan sekolah mitra, memutuskan untuk mengadakan pelatihan penggunaan Aplikasi Belajar Aksara Jawa yang bertempat di Laboratorium 4 FTI UKDW pada hari Jumat, 16 Oktober 2020. Acara ini rencananya dihadiri oleh 7 orang perwakilan Guru dari tiga sekolah, di antaranya 2 sekolah mitra dan satu sekolah yang pernah menjadi mitra pengabdian pada tahun sebelumnya. Ketujuh perwakilan guru tersebut adalah 2 orang dari SMA Budya Wacana, 2 orang dari SMA Immanuel Kalasan, serta 3 orang dari SMA BOPKRI I. SMA BOPKRI I memang menjadi bagian dari rencana Tim PkM untuk menambah mitra sesuai dengan rencana adaptasi. Namun karena waktu yang tidak memadai maka administrasi untuk keabsahan kerja sama mitra belum sempat dipenuhi. Meski demikian Tim PkM tetap mengundang perwakilan guru dari SMA BOPKRI I karena aplikasi ini sebelumnya sudah pernah diujicobakan di sekolah mitra tersebut dalam kerangka pengabdian insidental pada tahun 2019.

Sesi pertama adalah pelatihan penggunaan antar muka Aplikasi Belajar Aksara Jawa untuk Siswa. Suasana pelatihan ini diformat dalam bentuk tutorial, sehingga selama instruktur melakukan penjelasan, peserta pelatihan dapat langsung bertanya dan kemudian anggota Tim PkM lainnya akan membantu memberikan asistensi kepada peserta yang membutuhkan. Sesi ini membahas mengenai bagaimana nantinya para siswa akan menggunakannya dalam belajar, yaitu:

- Mendaftarkan diri pada sistem untuk mendapatkan login.

- Login ke sistem dan mekanisme lupa kata kunci.

- Memilih halaman buku aksara Jawa.

- Memilih baris kalimat yang akan digunakan untuk berlatih. 
- Mengerjakan latihan mengenali aksara Jawa: memilih aksara yang akan dikerjakan, memasukkan jenis aksara, merangkai aksara dan sandhangan atau pasangannya, memasukkan bunyi/bacaan aksara, menyimpan aksara dan melanjutkan ke aksara berikutnya, dan mengumpulkan baris aksara yang sudah dikerjakan.

- Melihat nilai dari pekerjaan siswa.

Pada sesi ini para guru berperan seolah-olah sebagai siswa, sehingga pada akhirnya nanti dapat memberikan instruksi yang sesuai pada para siswa-siswinya untuk menggunakan antar muka siswa. Terdapat sejumlah pertanyaan dan masukan dari para guru, termasuk mengenai sekuens atau urutan memasukkan aksara, sandhangan dan pasangan untuk mendapatkan hasil yang sesuai. Bagi beberapa guru yang berusia muda, mereka dapat mengerjakan lebih cepat tanpa pertanyaan berarti dari pada guru-guru yang sudah sepuh. Pertimbangan inilah yang menjadikan Tim PkM mengundang lebih dari satu guru per sekolah dengan komposisi tua-muda agar dapat saling membantu dalam penggunaannya nanti. Kegiatan pelatihan ini ditunjukkan oleh foto pada Gambar 8.

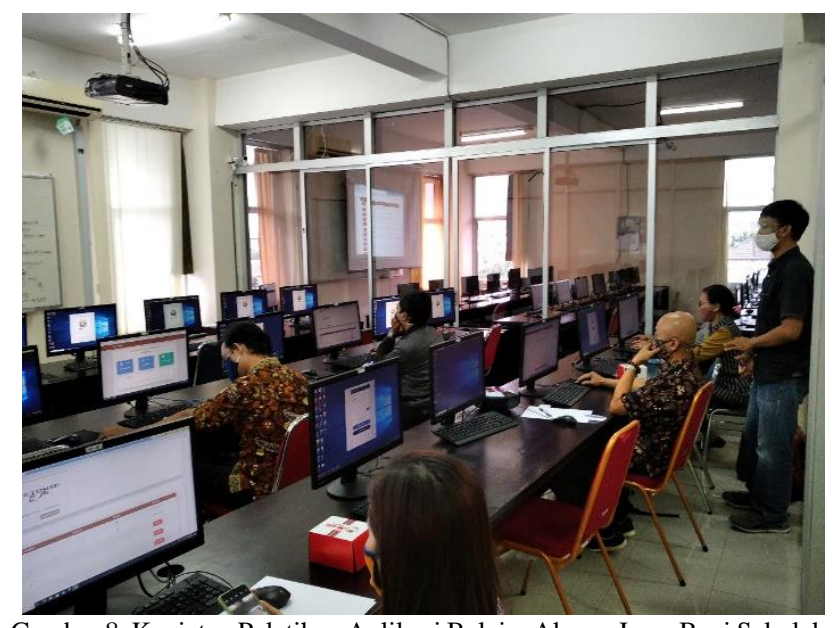

Gambar 8. Kegiatan Pelatihan Aplikasi Belajar Aksara Jawa Bagi Sekolahsekolah Mitra

Sesi ke dua adalah pelatihan penggunaan antar muka Aplikasi Belajar Aksara Jawa untuk Guru. Pada sesi ini tampak para guru lebih serius bertanya karena berkenaan dengan tugas dan kewajibannya. Sesi ini membahas fungsifungsi yang dapat dilakukan oleh para guru, di antaranya:

- Mendaftarkan diri pada sistem untuk mendapatkan login.

- Login ke sistem dan mekanisme lupa kata kunci.

- Memilih kelas siswa.

- Memilih pekerjaan siswa yang akan dinilai.

- Mekanisme penilaian: penilaian benar semua (mempermudah penilaian untuk siswa yang jawabannya benar seluruhnya).
- Mekanisme penilaian dengan koreksi: memilih aksara yang akan dikoreksi, memasukkan koreksi nama aksara dan pembacaannya, memberikan nilai angka.

- Menyimpan hasil penilaian untuk seorang siswa.

- Melihat daftar nilai.

Pada sesi ini cukup banyak pertanyaan yang dilontarkan para guru, terutama para guru yang sepuh mengenai mekanisme koreksi karena menggunakan alur yang berbeda dengan yang digunakan oleh siswa ketika memasukkan nama sebuah aksara dan bacaannya. Dijelaskan bahwa mekanisme tersebut memang sengaja dibuat berbeda karena untuk guru mempertimbangkan dua hal: fleksibilitas yang tinggi dan pengetahuan guru sendiri mengenai ranah ilmu bahasa dan sastra Jawa yang lebih luas dari pada siswa, sehingga alur dibuat lebih straightforward tetapi lebih fleksibel untuk mengkoreksi.

Kegiatan pelatihan ini kemudian diakhiri dengan masukan-masukan dan kesan-pesan dari para peserta baik mengenai penyelenggaraan pelatihan maupun Aplikasi Belajar Aksara Jawa. Para peserta menyambut baik dengan adanya pelatihan ini dan berharap agar pemanfaatan aplikas ini dapat membantu kondisi PJJ dan diperluas penggunaannya ke sekolah-sekolah lain. Terdapat peserta yang menyarankan, apabila aplikasi ini sudah disempurnakan, Tim PkM dapat mencoba melakukan wawan wicara dengan MGMP (Musyawarah Guru Mata Pelajaran) Bahasa Jawa di Yogyakarta. Adapun masukan dari para guru sekolah mitra mengenai aplikasi ini adalah:

- Tulisan Jawa yang ditampilkan sebagai soal sebaiknya diperbaiki perataan vertikalnya karena saat ini masih semuanya menempel rata atas, baik itu aksara yang memiliki sandhangan maupun tidak, sehingga dapat membingungkan siswa-siswi yang tidak memiliki latar belakang Bahasa Jawa.

- Urutan pemasukan aksara beserta sandhangan dan pasangannya pada antar muka siswa agar dibuat lebih jelas lagi sehingga mudah diingat. Terutama untuk aksara yang memiliki sandhangan lebih dari satu, sekaligus memiliki pasangan.

- Cek validasi penyimpanan pekerjaan maupun penilaian karena pada beberapa kesempatan masih terdapat pekerjaan maupun penilaian yang tidak tersimpan padahal pengguna sudah menekan tombol simpan.

- Antar muka disesuaikan untuk penggunaan pada gawai, seandainya larangan bertatap muka selama pandemi ini masih berlanjut pada tahun depan.

- Agar dibuat video tutorial yang dapat diakses secara daring untuk mengingatkan kembali langkahlangkah penggunaan dan mendampingi buku panduan yang telah ada.

- Tim PkM sangat menghargai masukan dari para guru dan sebelum para guru meninggalkan tempat 
pelatihan, Tim PkM meminta kontak yang dapat dihubungi untuk menindak lanjuti keberlangsungan penggunaan aplikasi dan menyampaikan jika terdapat update.

\section{F. Pembuatan Video Petunjuk Penggunaan Aplikasi}

Menindak lanjuti usulan dari para guru peserta pelatihan pada subbab E, Tim PkM membuat video tutorial untuk menggunakan Aplikasi Belajar Aksara Jawa. Video ini tersedia di https://trawaca.id/sinau/BlajarAksaraJawa.mp4 dan dapat diakses dari jaringan Internet. Video ini berisi alur penggunaan aplikasi diiringi dengan narasi pengantar fungsi setiap layar.

\section{G. Strategi Keberlanjutan Kegiatan PkM}

Sesuai saran dan masukan dari sekolah-sekolah mitra dalam pelaksanaan $\mathrm{PkM}$ periode ini maupun sebelumnya, Tim PkM terus berusaha menyempurnakan Aplikasi Belajar Aksara Jawa agar sesuai dengan target pengabdian yaitu para siswa dan guru Sekolah Menengah Atas. Setiap langkah penyempurnaan akan diiringi dengan komunikasi dan sosialisasi kepada sekolah mitra, dan juga diharapkan dapat menambah sekolah-sekolah mitra yang baru, agar semakin banyak yang dapat memanfaatkan aplikasi ini. Usulan dari guru-guru untuk membawa aplikasi ini ke forum MGMP Bahasa Jawa di Yogyakarta juga dapat menjadi sarana yang baik untuk menjaga keberlanjutan kegiatan PkM ini.

\section{KESIMPULAN}

Pandemi COVID-19 mengubah rencana pelaksanaan rencana kegiatan Pengabdian kepada Masyarakat ini, karena dikeluarkannya PSBB yang berakibat dihentikannya sementara kegiatan belajar mengajar (KBM) tatap muka luring untuk waktu yang belum ditentukan. Hal ini sangat berpengaruh karena mitra PkM adalah sekolah, dan seluruh rencana kegiatan pelatihan dan pendampingan semula dilaksanakan dalam bentuk pertemuan tatap muka di lokasi sekolah mitra. Ketika pada akhirnya diputuskan bahwa KBM dilaksanakan secara daring, terdapat hal-hal yang harus disesuaikan oleh Tim PkM agar kegiatan PkM dapat terus terlaksana.

Hadirnya konsep transformatif dan adaptif oleh LPPM UKDW dan kebijakan-kebijakan yang mengikutinya saat kondisi pandemi ini, cukup memberikan angin segar sehingga Tim PkM dapat sedikit leluasa untuk melakukan penyesuaian yang diperlukan. Memang benar bahwa pelaksanaan PkM harus transformatif dan adaptif, dalam arti jika terdapat perubahan kondisi di lapangan baik minor maupun mayor - dalam kondisi force majeure seperti pandemi ini - pelaksana PkM harus dapat beradaptasi agar target kegiatan, terutama yang berdampak langsung bagi mitra atau objek PkM, tetap dapat terwujud. Adaptasi yang diterapkan, walaupun berujung pada perubahan bentuk kegiatan, juga dihargai oleh ke dua belah pihak, baik Tim PkM maupun mitra, karena semua merasa bahwa dalam keterbatasan protokol pandemi ini, kegiatan yang masih dapat dilakukan harus terus dilaksanakan, sedangkan yang tertunda atau terbatalkan harus dimaklumi.

Pengalaman pelaksanaan PkM dalam kondisi pandemi seperti ini menjadi hal yang berharga, karena adaptasi dan transformasi tidak hanya terjadi pada Tim PkM selaku pelaksana, tetapi juga pada mitra PkM, yang beradaptasi selain dengan pelaksanaan PkM juga dengan kegiatan internal yang mereka lakukan sehari-hari. Koordinasi dan kesepakatan menjadi kunci agar semua pihak yang terlibat dapat tetap melaksanakan agenda yang dirancang secara sinkron. Tim PkM dan mitra sekolah juga saling berbagi solusi adaptasi yang bermanfaat, tidak hanya untuk pelaksanaan PkM tetapi juga bagi kegiatan internal masingmasing. Aplikasi Belajar Aksara Jawa yang dibagi-guna oleh Tim PkM, diapresiasi para guru sekolah mitra untuk dapat membantu keterbatasan pembelajaran Bahasa Jawa terutama pada pokok bahasan Aksara Jawa, pada pelaksanaan pembelajaran jarak jauh (PJJ) di sekolah mitra. Aplikasi ini juga dapat diperluas penggunaannya tidak pada taraf SMA saja tetapi juga SMP dengan menyesuaikan materi latihan aksara Jawa yang diberikan.

\section{UCAPAN TERIMA KASIH}

Para penulis selaku Tim Pengabdian kepada Masyarakat Universitas Kristen Duta Wacana menghaturkan terima kasih setinggi-tingginya kepada Lembaga Penelitian dan Pengabdian Masyarakat (LPPM) Universitas Kristen Duta Wacana Yogyakarta atas kesempatan dan dukungannya dalam menyelesaikan kegiatan PkM 2020 di SMA Immanuel Kalasan dan SMA Budya Wacana Yogyakarta.

\section{DAFTAR PUSTAKA}

[1] M. Dhoki, T. Siagian, Sukim, I. Wulansari, D. Hadi dan N. Sambodo, "Analisis Kearifan Lokal Ditinjau Dari Keragaman Budaya Tahun 2016,” PDSPK Kemdikbud RI, Jakarta, 2016.

[2] T. O. Randhir, "Globalization impacts on local commons: multiscale strategies for socioeconomic and ecological resilience," International Journal of the Common, vol. 10, no. 1, p. 387-404, 2016.

[3] G. Simons, "List of Languages by Total Number of Native Speaker," Ethnologue: Languages of the World, 21 February 2019.

[4] S. Malabar, "Pelestarian Bahasa Daerah Sebagai Media Revolusi Mental," dalam Prosiding Seminar Nasional Pendidikan Bahasa dan Sastra sebagai Media Revolusi Mental Generasi Masa Depan, Surabaya, 2016.

[5] H. Muklis, "Pahami Remaja Generasi Z," AF Education and Lifestyle Magazine, pp. 17-21, November 2015. 
[6] A. J. Nicholas, "Preferred Learning Methods of Generation Z," Salve Regina University, Newport, 2020.

[7] A. Krajina, "Generation Y and Generation $Z$ visual attention in the online environment: evidence from eye tracking and laddering," dalam 2018

NeuroPsychoEconomics Conference, Zurich, 2018.

[8] L. Krisnawati dan A. Mahastama, "Pelatihan Anotasi Aksara Jawa Melalui Program Aplikasi Cakra," dalam Prosiding Seminar Nasional Hasil Pengabdian Kepada Masyarakat, Semarang, 2019.

[9] Suharyanto dan A. Mailangkay, "Penerapan E-learning Sebagai Alat Bantu Mengajar Dalam Dunia Pendidikan," Jurnal Ilmiah Widya, vol. 3, no. 4, pp. 17-21, 2016.

[10] J. Sela, V. P. K. Lengkong dan I. Trang, "Pengaruh Kompetensi Dan Desain Pelatihan Terhadap Efektivitas Pelatihan Guru Sma/Smk/Ma Manado Pada Dinas Pendidikan Daerah Provinsi Sulawesi Utara," Jurnal EMBA, vol. 6, no. 4, pp. 2368-2377, 2018. 